\title{
Modulation of RAGE and the Downstream Targets of RAGE Signaling Cascades by Taurine in Lycium Barbarum (Goji Berry): Protection of Human Retinal Pigment Epithelial Barrier Function and its Potential Benefit in Diabetic Retinopathy
}

\section{M.K Song, B. D. Roufogalis* and T.H.W Huang*}

Faculty of Pharmacy, Herbal Medicine Group, The University of Sydney, NSW 2006, Australia

\begin{abstract}
Background: Retinal pigment epithelial (RPE) barrier disruption is an early event in diabetic retinopathy (DR). However, the biochemical details of its pathophysiology and treatment options are unclear. Taurine is reported to be beneficial in DR and is abundant in the fruit of Lycium barbarum (Goji Berry, LB). Hence, we have investigated the effect of taurine pure compound and an extract of LB extract rich in taurine on a model of DR, the ARPE-19 cell line treated with high glucose, and whether their effects on RPE barrier disruption by glucose may contribute to protection against DR.

Methods: The levels of NF-KB and ICAM-1 activity were measured by luciferase reporter gene analysis. Protein levels of RAGE and VEGF were determined by Western blot analysis. VEGF secretion levels were analysed by ELISA. The barrier function was determined by measuring TER and FITC-dextran permeability. Distribution of claudin-1 and connexin 43 proteins was examined by Western blot and immunofluorescence analysis.

Results: Taurine and an extract of LB rich in taurine dose-dependently down-regulate increased levels of RAGE, NF-KB, VEGF and ICAM-1 in the ARPE-19 cell line exposed to $33.3 \mathrm{mM}$ glucose. This reversal was associated with attenuation of high glucose-induced RPE barrier disruption, which was shown by increased TER, reduced FITCdextran permeability, characteristic morphological staining and dose-dependent modulation of claudin-1 and connexin 43 protein expression.

Conclusions: Pure taurine and LB extract protect against barrier disruption following exposure of ARPE-19 cells to high glucose. These effects are associated with altered NF-KB, ICAM-1 activity and VEGF secretion. Taurine and LB extract decrease RAGE. As they are known to activate PPAR-y we propose that their effects on barrier disruption may occur through their effects on RAGE and the downstream targets of RAGE signaling cascades. This pathway provides a rationale for the potential of taurine and the LB extract for protection against progression of DR.
\end{abstract}

Keywords: Lycium barbarum; Taurine; Advanced glycation end products; Peroxisome proliferator activated receptor- $\gamma$; Diabetic retinopathy; Human retinal pigment epithelial cell

Abbreviations: PPAR- $\gamma$ : Peroxisome Proliferator Activated Receptor- $\gamma$; LB: fruit from Lycium barbarum; ARPE-19: Human Retinal Epithelial Cell Line; DR: Diabetic Retinopathy; RG: Rosiglitazone; PG: 15-deoxy- $\Delta^{12,14}$-Prostaglandin $\mathrm{J}_{2}$; AGEs: Advanced Glycation End Products; RAGE: Receptor Advanced Glycation End Products; ICAM1: Intercellular Adhesion Molecule-1; VEGF: Vascular Endothelial Growth Factor; TER: Transepithelial Electrical Resistance; BRB: Blood Retinal Barrier

\section{Introduction}

Diabetic retinopathy (DR) is one of the most common microvascular complications of diabetes and remains a major cause of preventable blindness worldwide [18]. The retinal pigment epithelial (RPE) cells form an important permeability barrier, the blood retinal barrier (BRB), between the sensory retina and the choriocapillaris, and play a key role in the pathogenesis of DR $[1,60]$.

Chronic hyperglycemia is believed to be the primary pathogenic factor for inducing damage to pigment epithelial cells [14]. This results in changes to the pattern of production of a number of proinflammatory mediators, followed by angiogenesis in tissue remodeling, and finally increase in retinal vasopermeability and disruption of the BRB $[11,22,64]$. Moreover, degradation of high glucose-induced RPE cells leads to down-regulation of the gap junction protein connexin 43 and up-regulation of the tight junction protein claudin-1, causing disruption of the epithelial barrier function [1,34].

One of the underlying pathophysological mechanisms associated with hyperglycemia-induced DR is excessive formation of advanced glycation end products (AGEs) and subsequent interaction with their receptor advanced glycation end products (RAGE) [54]. Activation of RAGE results in oxidative stress, and the subsequent activation of NF- $\mathrm{KB}$ transcription factor is considered to be linked to epithelial

*Corresponding authors: Basil D Roufogalis, Faculty of Pharmacy, The University of Sydney, NSW 2006, Australia, Tel: +61 29351 2360; Fax: +61 2 9351 4391; E-mail: basil.roufogalis@sydney.edu.au

Tom Hsun-Wei Huang, Faculty of Pharmacy, The University of Sydney, NSW 2006 Australia, Tel: +61 29351 3234; E-mail: thwh@yahoo.com

Received November 15, 2011; Accepted December 19, 2011; Published December 23, 2011

Citation: Song MK, Roufogalis BD, Huang THW (2011) Modulation of RAGE and the Downstream Targets of RAGE Signaling Cascades by Taurine in Lycium Barbarum (Goji Berry): Protection of Human Retinal Pigment Epithelial Barrie Function and its Potential Benefit in Diabetic Retinopathy. J Diabetes Metab 2:162. doi:10.4172/2155-6156.1000162

Copyright: (c) 2011 Song MK, et al. This is an open-access article distributed unde the terms of the Creative Commons Attribution License, which permits unrestricted use, distribution, and reproduction in any medium, provided the original author and source are credited. 
Citation: Song MK, Roufogalis BD, Huang THW (2011) Modulation of RAGE and the Downstream Targets of RAGE Signaling Cascades by Taurine in Lycium Barbarum (Goji Berry): Protection of Human Retinal Pigment Epithelial Barrier Function and its Potential Benefit in Diabetic Retinopathy. J Diabetes Metab 2:162. doi:10.4172/2155-6156.1000162

dysfunction [36]. These cascade episodes trigger serum components and inflammatory cells to enter the vitreous cavity and sub-retinal space, exposing the RPE cells to pro-inflammatory mediators, including intercellular adhesion molecule-1 (ICAM-1) and vascular endothelial growth factor (VEGF), causing BRB breakdown and vascular leakage, leading to further progression of DR $[29,60]$.

Recent studies have shown that retinal expression of PPAR- $\gamma$ was suppressed in experimental models of diabetes and in endothelial cells treated with high glucose [55]. Administration of 15-deoxy- $\Delta^{12,14}$ prostaglandin $\mathrm{J}_{2}\left(15 \mathrm{~d}-\mathrm{PG} \mathrm{J}_{2}\right.$ ) inhibited VEGF-stimulated angiogenesis in rat cornea [63]. Rosiglitazone has been found to inhibit retinal endothelial cell proliferation, migration, and tube formation in response to VEGF treatment [56]. A body of evidence has shown that PPAR- $\gamma$ ligands inhibit the formation of AGEs [47,51]. Moreover, rosiglitazone has been shown to inhibit both retinal leukostasis and retinal leakage by the inhibition of NF- $\kappa \mathrm{B}$ activation, with consequent suppression of ICAM-1 expression [42]. These findings suggest that PPAR- $\gamma$ is involved in the pathogenesis of DR [52].

Fruit from Lycium barbarum L (LB) in the family Solanaceae is well-known in traditional Chinese medicine [35]. LB has been widely used in functional food products with a large variety of reported beneficial effects, such as reducing blood glucose, neuroprotection, and anti-inflammatory activity [5,45,61]. There is a growing body of evidence indicating that LB intake increases the fasting plasma zeaxathin levels, beneficial for maintaining macular pigment density in age-related macular degeneration [9]. Moreover, LB has been shown to be effective in the treatment of glaucoma and modulating immunity in retinal ganglion cells in a rat hypertension model $[7,10]$. However, the beneficial effect of LB and its possible mechanisms in DR has not been studied. LB contains taurine, a non-essential free amino acid, which is one of the most abundant chemical components present in this plant $[6,62]$. Taurine has been recommended as a complementary therapeutic agent for the prevention of diabetic complications in type II diabetes [39].

Despite the growing body of evidence both from in vitro and animal research for LB in various medical applications in recent years, there is limited research available to establish its efficacy and mode of action in modulating eye related pathology. Moreover, the taurine component of LB needs to be further investigated through molecular biology to pinpoint its therapeutic potential for the treatment of DR. Recently, we have shown that LB and, taurine, its abundant active component, may delay DR through the PPAR- $\gamma$ pathway [53]. However, the beneficial effect of taurine and LB on DR by modulation of high glucose induceddisruption of RPE barrier function through the downstream targets of RAGE signaling cascades have not been extensively investigated. Therefore, the aim of this study is to investigate the relationship between the receptor function of pure taurine and an extract of LB rich in taurine in the modulation of parameters of retinal barrier permeability in a high glucose-treated retinal cell line model.

\section{Methods and Materials}

\section{Preparation of LB extract}

Dried LB was purchased in raw powder form (batch no.53101: DeDu Holdings, West Ryde, Australia). The preparation of an extract of LB was performed as previously described [21,53] with modifications. Briefly, $250 \mathrm{mg}$ of fine LB powder was extracted with 2.5 $\mathrm{ml}$ of methanol by sonication at room temperature for $15 \mathrm{~min}$ followed by centrifugation for $5 \mathrm{~min}$. This step was repeated four times. The solvent was then evaporated under reduced pressure below $50^{\circ} \mathrm{C}$ and the remaining solid collected. The identification and quantification of taurine in the LB extract was undertaken by thin layer chromatography (TLC) analysis, as previously described [53].

\section{Tissue culture}

The human retinal epithelial cell line, ARPE-19 was a kind gift from Dr Weiyong Shen (Save Sight Institute, Sydney, Australia). The cells were cultured as previously described [16]. Briefly, the cells were cultured in a humidified incubator at $37^{\circ} \mathrm{C}$ in $5 \% \mathrm{CO}_{2}$ in $10 \%$ fetal bovine serum-defined minimal essential medium (FBS-DMEM-F12 medium) containing $5.5 \mathrm{mM}$ glucose, supplemented with $100 \mathrm{U} / \mathrm{ml}$ penicillin $\mathrm{G}$ and $100 \mu \mathrm{g} / \mathrm{ml}$ streptomycin. The culture medium was replaced with fresh medium every second day. Upon confluence, cultures were passaged by dissociation in $0.05 \%(\mathrm{w} / \mathrm{v})$ trypsin (GibcoLife Technologies, Roseville, MD, USA) in phosphate buffered saline (PBS) $\mathrm{pH}$ 7.4. Cytotoxicity of LB extract and taurine used in the experiments were examined by MTS assay (Promega, Australia) and they showed little or no effect on cell viability ( $>90 \%$ viability remained) (data not shown)

For high glucose-induced functional studies, cells were maintained in fresh medium containing $1 \%$ FBS for $2 \mathrm{~h}$ prior to use in the experiments. Cells were then treated with samples, rosiglitazone (RG), and $15 \mathrm{~d}-\mathrm{PGJ}_{2}$ (PG) or vehicle (0.5\% DMSO) for $6 \mathrm{~h}$. The treatment with extract and drug samples was continued for $48 \mathrm{~h}$ during the incubation in normal $(5.5 \mathrm{mM})$ or high $(33.3 \mathrm{mM}) \mathrm{D}$-glucose. Cells incubated in $27.5 \mathrm{mM}$ mannitol (M) served as an osmotic control [67]. The cells used in these experiments were between passages 20 and 24 .

\section{Transfection and luciferase analysis of NF- $\kappa$ B and ICAM-1 luciferase activity}

To determine NF- $\kappa \mathrm{B}$ and ICAM-1 luciferase activity, the ARPE19 cells were transiently transfected, as previously described with modifications $[17,28,40]$. The plasmids used for transfection were p-NF- $k B-L u c$ (a kind gift from Dr Sheridan Henness, The University of Sydney, Australia), p-ICAM-Luc (a kind gift from Dr Young-Guen Kwon, Younsei University, Korea) and pSV- $\beta$-Galactosidase Control Vector (Promega, Australia) to normalize transfection efficiencies.

Cells were transfected with FuGENE6 transfection reagent (Roche, Australia) in accordance with the manufacturer's instructions. At 48 $\mathrm{h}$ before transfection, ARPE- 19 cell line was seeded at $5 \times 10^{5}$ cells/T25 flask in $5 \mathrm{ml}$ of Dulbecco's modified Eagle's medium/F-12 containing $10 \%$ FBS and supplemented with $1 \%$ penicillin and streptomycin, $1 \%$ L-glutamine, $20 \mathrm{mM}$ HEPES and $5.5 \mathrm{mM} \mathrm{D}$-glucose. After $48 \mathrm{~h}$, the cells were then harvested and plated into 96-well plates at $3 \times 10^{4}$ cells per well in complete transfection media and allowed to attach for 12 h. The cells were then replaced with serum free media containing $1 \%$ FBS for $2 \mathrm{~h}$ prior to use in the experiments. Cells were treated with the PPAR- $\gamma$ positive controls (RG and PG), test samples, TNF- $\alpha$ (a known activator of NF- $\kappa$ B and ICAM-1) $[48,50]$ or vehicle (0.5\% DMSO) for 6 $\mathrm{h}$ followed by further exposure to normal $(5.5 \mathrm{mM})$ or high $(33.3 \mathrm{mM})$ $\mathrm{D}$-glucose. After $48 \mathrm{~h}$, the cells were lysed and assayed for luciferase and $\beta$-galactosidase activities using the Bright-Glo Luciferase Assay System and Beta-Glo Assay System (Promega, Australia), respectively. There results were expressed as relative luciferase activity (fold difference compared to negative control).

\section{Protein extraction and semi-quantitative immunoblotting}

Immunoblots were conducted as described previously [13]. The 
Citation: Song MK, Roufogalis BD, Huang THW (2011) Modulation of RAGE and the Downstream Targets of RAGE Signaling Cascades by Taurine in Lycium Barbarum (Goji Berry): Protection of Human Retinal Pigment Epithelial Barrier Function and its Potential Benefit in Diabetic Retinopathy. J Diabetes Metab 2:162. doi:10.4172/2155-6156.1000162

proteins from the cells were prepared using the Ripa lysis buffer (25 mM Tris buffer (pH 7.6), $150 \mathrm{mM} \mathrm{NaCl}, 1 \% \mathrm{NP}-40,1 \%$ sodium deoxycholate, $0.1 \%$ SDS). The lysed cells were centrifuged at 12,000 rpm (Micromax RF centrifuge, Thermo IEC, MA, USA) for 10 min and supernatants resolved by SDS-PAGE, 4-12\% (Invitrogen, Australia). Protein was transferred to cellulose membrane with transfer buffer (Tris base 25mM, glycine $192 \mathrm{mM}, \mathrm{pH} 8.3$ ) and blocked in 5\% skim milk powder (Sigma, Australia) overnight. The primary antibody were anti-RAGE mouse monoclonal (1:200 dilution), anti-VEGF mouse monoclonal (1:100 dilution) (Santa Cruz Biotechnology, USA), anticlaudin-1 mouse monoclonal (1:1000 dilution) and anti-Cx43 mouse monoclonal (1:1000 dilution) (Zymed Lab Gibco; Invitrogen, San Diego, CA, USA). After incubation with the primary antibody for $1 \mathrm{~h}$ at room temperature, the membrane was washed and further incubated with horseradish peroxidase conjugated anti-mouse secondary antibodies (1: 6000 dilution; Santa Cruz Biotechnology, USA). Bound antibodies were detected using enhanced chemiluminescence with Lumi-Light Western Blotting Substrate (Roche). The membranes were exposed to X-ray film (Kodak, USA) and developed using the SRX101A X-ray developer (Konica, Taiwan). The resultant films were quantified by scanning densitometry using ImageJ (National Institutes of Health, Bethesda, MD). Protein expression was quantified by normalisation to $a$-tubulin. Levels in control were arbitrarily assigned a value of 1.0. The membranes were re-probed with anti- $\alpha$-tubulin primary antibody (1:10,000 dilution; Santa Cruz Biotechnology, USA) after being stripped and overnight blotting with $5 \%$ skim milk. The membranes were re-incubated with horseradish peroxidase conjugated anti-mouse secondary antibody and detected using the same procedure as described above. Cell lysate protein concentrations were determined by the BCA (bicinchoninic acid) assay (Thermo, USA) according to the manufacturer's instructions.

\section{Measurement of VEGF levels by ELISA}

The levels of VEGF in cell supernatants were measured using ELISA kit (R\&D Systems, Minneapolis, MN, USA), as described previously [46]. The authors used medium alone without cells incubated under the same conditions as a blank control for the ELISA. VEGF levels were normalised to total protein, as determined by the BCA assay (Thermo, USA) according to the manufacturer's instructions.

\section{Measurement of barrier functions}

Cells were seeded on $12-\mathrm{mm}$ diameter, $0.4-\mu \mathrm{m}$ pore size, polyester transwell filters (Coster, Corning Inc, NY, USA) at $1.0 \times 10^{5}$ cells/well in $0.5 \mathrm{ml}$ of growth medium containing $5.5 \mathrm{mM}$ glucose. $1 \mathrm{ml}$ of medium was added at the basal chambers to level the height of the liquid for preventing hydrostatic pressure. Transepithelial electrical resistance (TER) of cell monolayers was measured using an epithelial volt-meter (EVOM; World Precision Instruments, Sarasota, FL) according to the manufacturer's instructions. Briefly, the cells were taken from the incubator and placed at room temperature for $30 \mathrm{~min}$ of equilibration before the measurements. The TER (in ohms. $\mathrm{cm}^{2}$ ) of the filter alone was measured as background and subtracted from the TERs obtained with the filters containing the ARPE-19 cells. Measurements were repeated six times for each well, and each experiment was repeated in five different wells.

The permeability of the ARPE-19 cells was determined by measuring the apical to basolateral movements of fluorescein isothiocynate (FITC)-dextran $(70 \mathrm{kDa})$. The test molecule was added to the apical compartment of the cells in a concentration of 1.43 $\mu \mathrm{M}$. Five hours later, $200 \mu \mathrm{l}$ of sample from the basolateral chamber was collected and the fluorescence intensity was measured using a fluorometer at an excitation wavelength of $485 \mathrm{~nm}$ and an emission wavelength of $520 \mathrm{~nm}$. A minimum of three cultures were used for each time measurement.

\section{Immunofluorescence detection}

To study the distribution and relative amounts of claudin- 1 and connexin 43, RPE monolayers maintained on glass cover slips (Livingstone International, Rosebery, Australia) were immunostained for claudin-1 and Connexin 43 proteins, as described previously [25]. Briefly, cells were washed twice in PBS for $5 \mathrm{~min}$, fixed with $4 \%$ paraformaldehyde for $10 \mathrm{~min}$ followed by two washes with PBS. Cells were then permeabilised with $0.1 \%$ triton X-100 (Sigma-Aldrich, St. Louis, MO, USA) for 10 min and blocked with $5 \%$ bovine serum albumin (BSA) for $30 \mathrm{~min}$ at RT. Mouse anti-claudin-1 (1:200 dilution) and connexin 43 (1: 200 dilution) antibodies (Zymed Laboratories Inc., San Francisco, CA) were incubated overnight at $4^{\circ} \mathrm{C}$. After washing with PBS, cells were further incubated with Alexa 568 goat anti-mouse secondary antibody (Invitrogen, Australia) for $1 \mathrm{~h}$ at RT. After several washes with PBS, Hoechst 33342 was added for the counterstaining of the cell nuclei. Coverslips were then mounted onto glass slides using antifade reagent (Invitrogen, Australia) and examined under a fluorescence microscope (DMI3000B: Leica Microsystems Imaging Solution, Ltd.). For quantification, the fluorescence intensity (mean gray values) of images was measured using Image J software. Images were analysed from four randomly selected X63 images from the same sets of experiments [41]. In addition, we measured the florescence intensity of the background, which was later subtracted from the values obtained from the images.

\section{Chemicals}

Rosiglitazone was purchased from Alexis Biochemicals (San Diego, Calif, USA). Pure taurine compound, 15-deoxy-Delta $(12,14)$-prostaglandin J fluorescein isothiocynate (FITC)-dextran and other chemicals were purchased from Sigma-Aldrich (St. Louis, MO, USA), unless otherwise indicated.

\section{Statistical analysis}

All results are expressed as means \pm S.E.M. Data was analysed by 1 -factor analysis of variance (ANOVA). If a statistically significant effect was found, the Newman-Keuls test was performed to isolate the difference between the groups. $\mathrm{P}$ values less than $0.05(\mathrm{P}<0.05)$ were considered to indicate significance.

\section{Results}

\section{Effects of LB extract and taurine on RAGE protein expression activation in high-glucose treated ARPE-19 cells}

As hyperglycemia increases expression of the receptor for advanced glycation end products (RAGEs) [66] we determined the effect of LB extract and taurine on RAGE protein expression in high glucosetreated ARPE-19 cells.

Incubation with high glucose for $48 \mathrm{~h}$ induced a significant increase in the level of RAGE protein expression (9.70-fold) compared with normal glucose culture (Figure 1$)$. LB extract $(0.1,0.5$ and $0.75 \mathrm{mg} / \mathrm{ml}$ ) dose-dependently down-regulated RAGE protein expression (by 5.81-, 4.91- and 3.32-fold, respectively) (Figure 1a). Taurine (0.001, 0.1 and 1 $\mathrm{mM}$ ) dose-dependently down-regulated RAGE protein expression (by 5.76-, 4.59- and 3.25-fold, respectively) (Figure 1b). The protein levels of RAGE in high glucose treated cells were decreased by the positive 
Citation: Song MK, Roufogalis BD, Huang THW (2011) Modulation of RAGE and the Downstream Targets of RAGE Signaling Cascades by Taurine in Lycium Barbarum (Goji Berry): Protection of Human Retinal Pigment Epithelial Barrier Function and its Potential Benefit in Diabetic Retinopathy. J Diabetes Metab 2:162. doi:10.4172/2155-6156.1000162

controls, RG (2.75-fold) and PG (3.65-fold). The osmotic control did not enhance RAGE protein level, excluding the involvement of osmotic effects of the high glucose concentrations.

\section{Effects of LB extract and taurine on NF- $\kappa B$ luciferase activation in high-glucose treated ARPE-19 cells}

As hyperglycemia activates the pro-inflammatory transcriptional factor, NF- $\kappa \mathrm{B}[31$, we determined the effect of LB extract and taurine on NF- $\kappa \mathrm{B}$ luciferase activity in high glucose-treated ARPE-19 cells. Incubation with high glucose for $48 \mathrm{~h}$ induced a significant increase in NF- $\kappa$ B luciferase activity (7.77-fold), compared with normal glucose culture (Figure 2).

LB extract $(0.1,0.5$ and $0.75 \mathrm{mg} / \mathrm{ml})$ dose-dependently decreased NF- $\kappa \mathrm{B}$ activation by high glucose incubation (by 4.96-, 3.27- and 2.46fold, respectively). Taurine (0.001, 0.1 and $1 \mathrm{mM}$ ) dose-dependently decreased NF-kB activation by high glucose incubation (by 5.38-, 3.74- and 2.57-fold, respectively) (Figure 2). The NF- $\kappa$ B activity in high glucose treated cells was decreased by adding the positive controls, RG (3.22-fold) and PG (3.36-fold). The osmotic control did not enhance NF- $\kappa B$ luciferase activity, excluding the involvement of osmotic effects of high glucose concentrations.

Effects of LB extract and taurine on ICAM-1 luciferase activation and levels of VEGF in high-glucose treated ARPE-19 cells

As activation of RAGE and activation of NF- $\kappa B$ transcription factor, are considered to be linked to up-regulation of the levels of ICAM-1 and VEGF $[29,60]$, we investigated the effect of LB extract and taurine treatment on ICAM-1 activity (by luciferase assay), and levels of VEGF concentrations and protein expression.

Incubation with high glucose for $48 \mathrm{~h}$ induced a significant increase in ICAM-1 luciferase activity (5.01-fold), compared with normal glucose culture (Figure 3).

LB extract $(0.1,0.5$ and $0.75 \mathrm{mg} / \mathrm{ml})$ dose-dependently decreased ICAM-1 activation (by 4.31-, 3.29- and 2.74-fold, respectively). Taurine (0.001, 0.1 and $1 \mathrm{mM})$ dose-dependently decreased ICAM-1 activation (by 4.18-, 2.99- and 2.68-fold, respectively) (Figure 3). ICAM-1 activity in high glucose treated cells was also decreased by the positive controls, RG (2.28-fold) and PG (2.60-fold). The osmotic control did not enhance ICAM-1 luciferase activity, excluding the involvement of osmotic effects of high glucose concentrations.

Incubation with high glucose for $48 \mathrm{~h}$ induced a significant increase in VEGF concentration (to $427.6-\mathrm{pg} / \mathrm{ml}$ ) and protein expression (9.11fold), compared with normal glucose culture (Figure 4). LB extract $(0.1,0.5$ and $0.75 \mathrm{mg} / \mathrm{ml})$ dose-dependently decreased VEGF protein expression (by 6.73-, 5.21- and 3.57-fold, respectively) (Figure 4a). Taurine $(0.001,0.1$ and $1 \mathrm{mM})$ dose-dependently decreased VEGF protein expression (by 6.27-, 4.95- and 3.09-fold, respectively) (Figure $4 \mathrm{~b})$. The VEGF protein expression in high glucose treated cells was also decreased by the positive controls, RG (4.32-fold) and PG (2.95-fold).

LB extract $(0.1,0.5$ and $0.75 \mathrm{mg} / \mathrm{ml})$ dose-dependently decreased VEGF concentrations in high glucose (by 270.4-, 214.1- and 171.3-pg/ $\mathrm{ml}$, respectively). Taurine $(0.001,0.1$ and $1 \mathrm{mM})$ dose-dependently decreased VEGF concentrations in high glucose (by 300.6-, 197.9- and 189.7-pg/ml, respectively) (Figure 4c). The VEGF concentrations in high glucose treated cells were also decreased by adding the positive controls, RG (162.5-pg/ml) and PG (150.2-pg/ml). The osmotic control did not enhance levels of VEGF, excluding the involvement of osmotic effects of high glucose concentrations. (a)

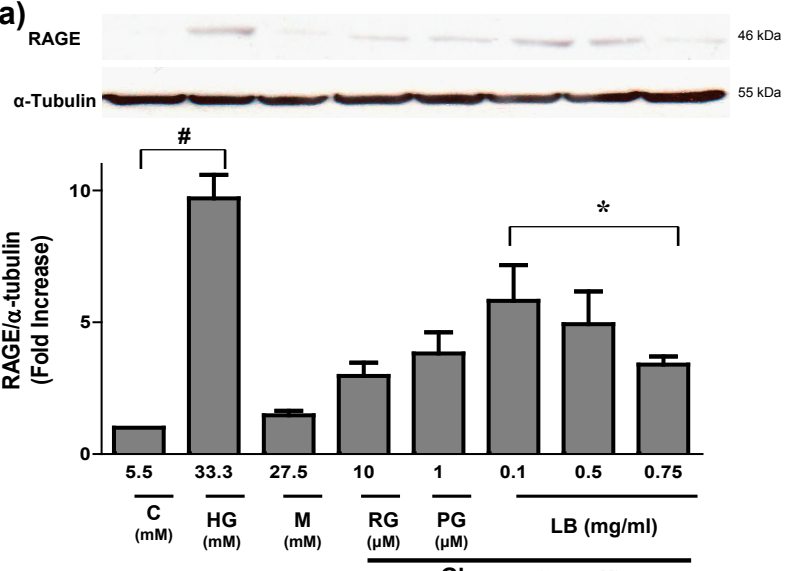

(b)

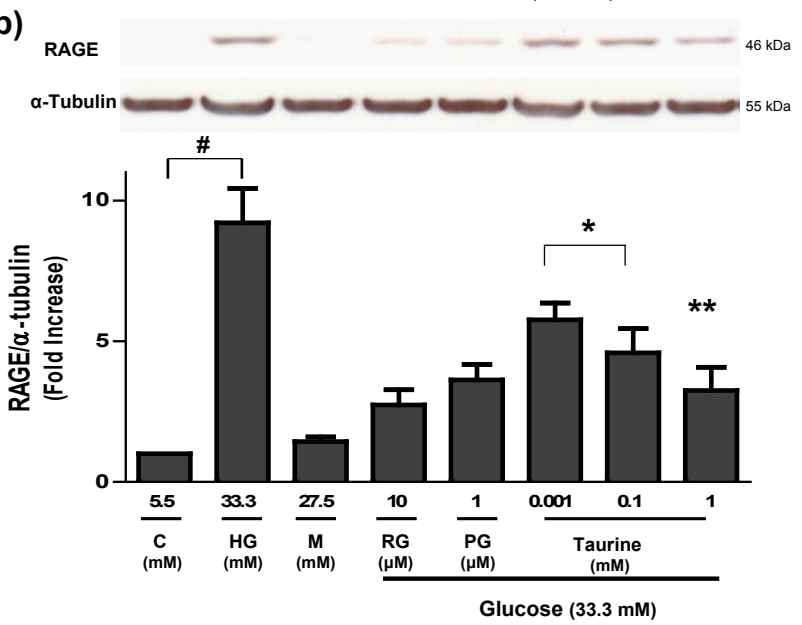

Figure 1: Effects of (a) LB extract (0.1. 0.5 and $0.75 \mathrm{mg} / \mathrm{ml}$ ) and (b) taurine (0.001, 0.1 and $1 \mathrm{mM}$ ) on protein expression of RAGE in high glucose-treated ARPE-19 cells. The relative levels of protein for RAGE was assessed by the immunoblotting method, and normalised to a-tubulin. Levels in control were arbitrarily assigned a value of 1.0 . Values are means \pm SEM $(n=4)$. ${ }^{\#} P<0.001$ versus Control, ${ }^{*} P<0.05,{ }^{* *} P<0.01$ versus high glucose $(\mathrm{HG})$. RG $(10 \mu \mathrm{M})$ and PG $(1 \mu \mathrm{M})$ were used as a positive controls. Mannitol (M) served as osmotic control.

\section{Effect of LB extract and taurine on barrier function in high glucose-treated ARPE-19 cells}

Increase in the levels of ICAM-1 and VEGF, caused by hyperglycemia, has been implicated in the disruption of RPE barrier function $[2,60]$. To investigate the effects of treatment with LB extract $(0.1,0.5$ and $0.75 \mathrm{mg} / \mathrm{ml})$ and taurine $(0.001,0.1$ and $1 \mathrm{mM})$ on RPE barrier function, TER and apical-basolateral movements of FITCdextran, indicators of a functional barrier, was measured in high glucose-treated ARPE-19 cells.

Incubation with high glucose for $48 \mathrm{~h}$ induced a significant decrease in transepithelial electrical resistance (TER) $\left(29.9 \mathrm{ohm} . \mathrm{cm}^{2}\right)$, compared with the normal glucose condition (Figure 5a). Incubations with LB extract and taurine dose-dependently increased TER across high glucose-treated ARPE-19 cells by 32.3-, 52.5- and 73.7-ohm.cm ${ }^{2}$ for 0.1 .0 .5 and $0.75 \mathrm{mg} / \mathrm{ml} \mathrm{LB}$, respectively and by $36.0-, 66.0-$ and 78.9-ohm. $\mathrm{cm}^{2}$ for $0.001,0.1$ and $1 \mathrm{mM}$ taurine, respectively (Figure 
Citation: Song MK, Roufogalis BD, Huang THW (2011) Modulation of RAGE and the Downstream Targets of RAGE Signaling Cascades by Taurine in Lycium Barbarum (Goji Berry): Protection of Human Retinal Pigment Epithelial Barrier Function and its Potential Benefit in Diabetic Retinopathy. J Diabetes Metab 2:162. doi:10.4172/2155-6156.1000162

Page 5 of 10

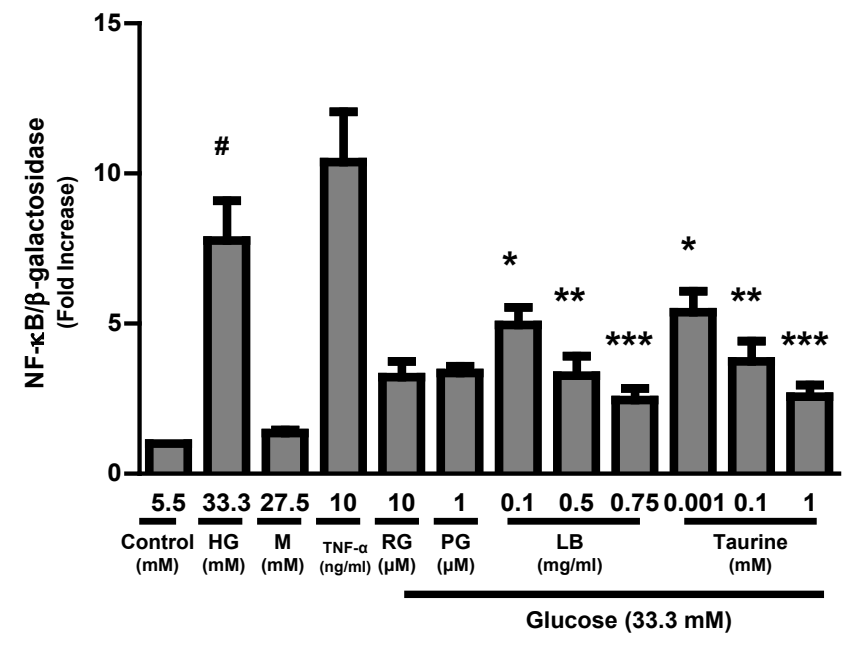

Figure 2: Effects of LB extract and taurine on NF-KB activity in high glucosetreated ARPE-19 cells transfected with NF-kB luciferase reporter gene. Levels in the control were arbitrarily assigned a value of 1.0 . Values are means \pm SEM $\left(n=4\right.$, each in triplicate). ${ }^{\#} P<0.001$ versus Control, ${ }^{*} P<0.05,{ }^{*} P<0.01,{ }^{* * *} P<0.001$ versus high glucose $(\mathrm{HG})$.

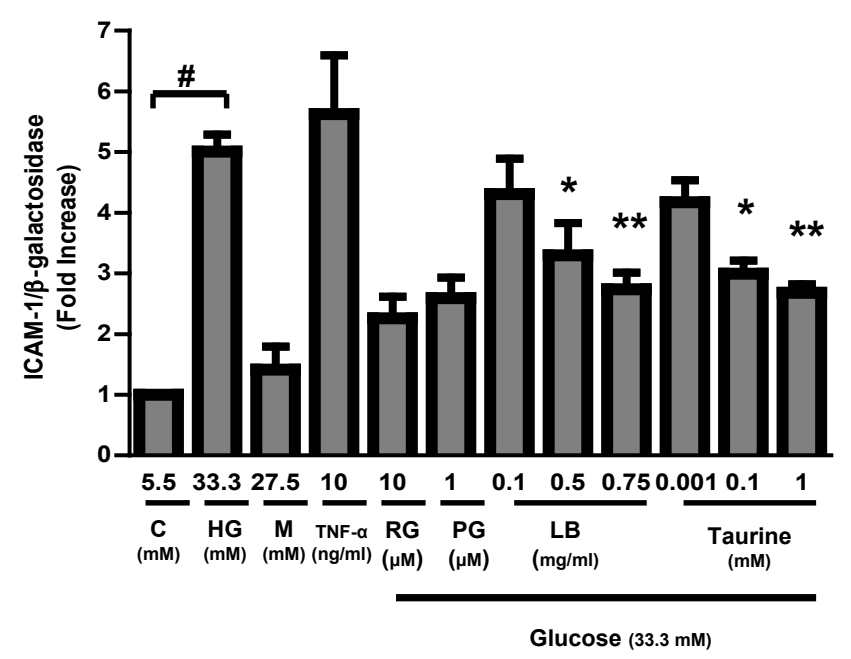

Figure 3: Effects of LB extract and taurine on ICAM-1 activity in high glucosetreated ARPE-19 cells transfected with ICAM-1 luciferase reporter gene. Levels in the control were arbitrarily assigned a value of 1.0. Values are means \pm SEM ( $n=4$, each in triplicate). ). ${ }^{\#} P<0.001$ versus Control, ${ }^{*} P<0.05,{ }^{* *} P<0.01$ versus high glucose (HG).

5a). TER in high glucose treated cells was also increased by adding the positive controls, RG (74.2- ohm.cm²) and PG (43.7- ohm.cm²).

Incubation with high glucose for $48 \mathrm{~h}$ induced a significant increase in FITC-dextran permeability to 3068.5- arbitrary units (AU), compared with the normal glucose condition (Figure 5b). Treatment with LB extract and taurine dose-dependently reversed the increased FITC-dextran permeability across the high glucose-treated ARPE-19 cells by 1897.3-, 1514.5- and 1271.3-AU for 0.1 .0 .5 and $0.75 \mathrm{mg} / \mathrm{ml}$ LB, respectively and by 2070.1-, 1537.6- and 1199.7-AU for 0.001, 0.1 and $1 \mathrm{mM}$ taurine, respectively (Figure $5 \mathrm{~b}$ ). FITC-dextran permeability in high glucose treated cells was also decreased by adding the positive controls, RG (1151.6-AU) and PG (1457.7-AU). The osmotic control did not significantly alter the barrier function, excluding the involvement of osmotic effects of high glucose concentrations.
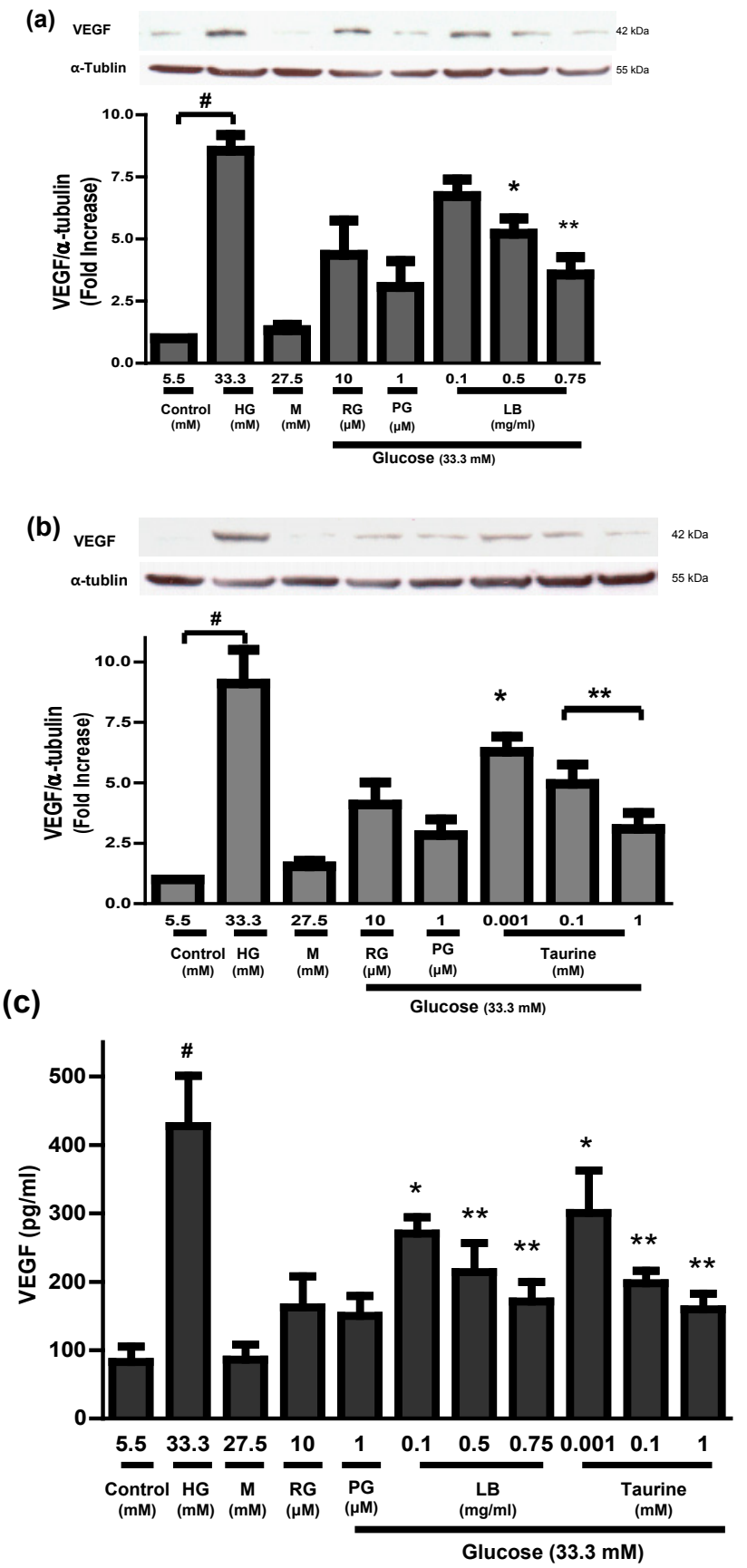

Figure 4: Effects of LB extract (a) and taurine (b) on protein expression of VEGF in high glucose-treated ARPE-19 cells. The relative levels of protein for VEGF was assessed by the immunoblotting method, and normalised to a-tubulin. Levels in control were arbitrarily assigned a value of 1.0. Values are means \pm SEM. $(n=6)$. (c) Effects of LB extract and taurine on levels of VEGF concentrations in high glucose-treated ARPE-19 cells. VEGF levels in the supernatants were measured by ELISA. Values are means \pm SEM. $(n=4$, each in triplicate). ${ }^{\#} P<0.001$ versus Control, ${ }^{*} P<0.05,{ }^{*} P<0.01$ versus high glucose (HG). 
Citation: Song MK, Roufogalis BD, Huang THW (2011) Modulation of RAGE and the Downstream Targets of RAGE Signaling Cascades by Taurine in Lycium Barbarum (Goji Berry): Protection of Human Retinal Pigment Epithelial Barrier Function and its Potential Benefit in Diabetic Retinopathy. J Diabetes Metab 2:162. doi:10.4172/2155-6156.1000162
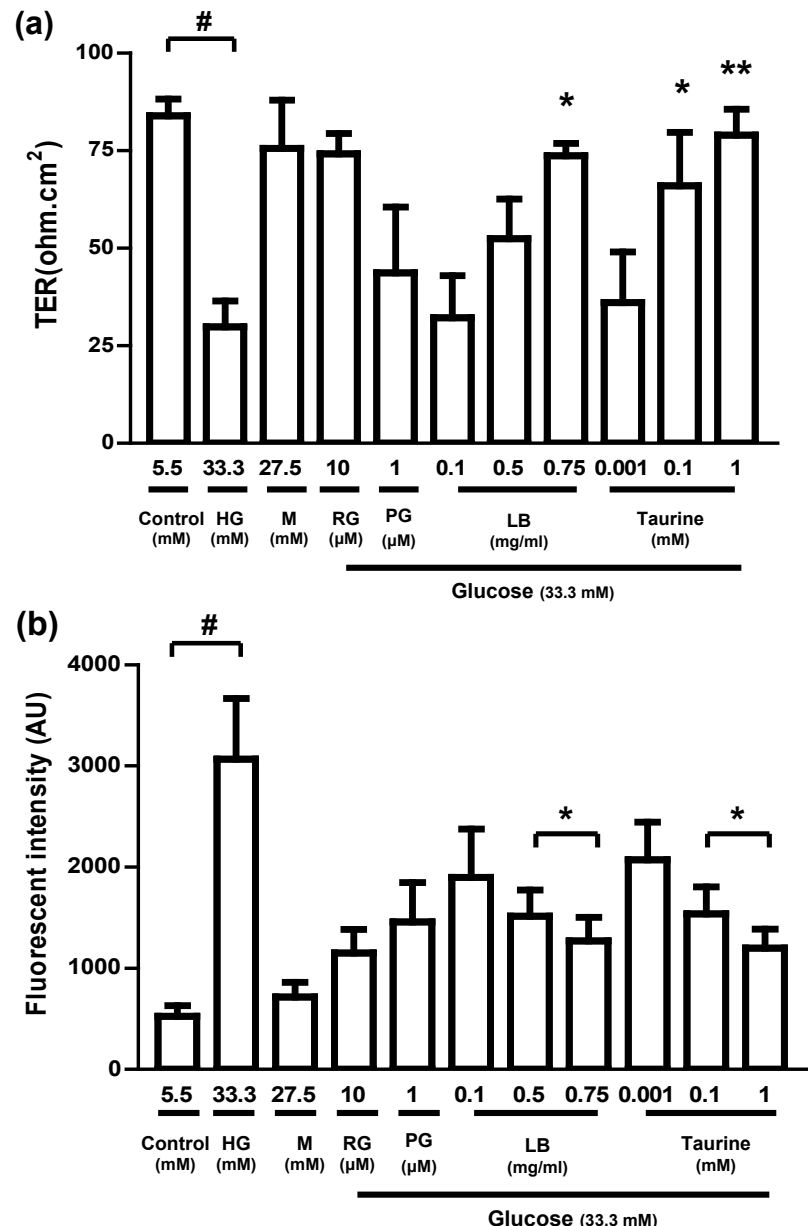

Figure 5: The role of LB extract and taurine in high glucose-induced breakdown of the epitheleal barrier in ARPE-19 monolayer. (a) The effect of LB extract and taurine on integrity of tight junctions between ARPE-19 cells was determined by transepithelial resistance (TER) values. The vertical axis represents the TER expressed in $\mathrm{Ohm}^{\circ} \mathrm{cm}^{2}$. (b) The effect of LB extract and taurine on $70 \mathrm{kDa}$ FITCdextran permeability in high glucose-treated ARPE-19 cells was determined. The vertical axis represents the fluorescent intensity. Values are means \pm SEM ( $n=5$ independent experiments). ${ }^{\#} P<0.01$ versus Control, ${ }^{*} P<0.05,{ }^{* *} P<0.01$ versus high glucose $(\mathrm{HG}) . A U$, arbitrary units.

Effects of LB extract and taurine on claudin-1 protein expression in high-glucose treated ARPE-19 cells

The up-regulation of claudin-1 occurs in the dysfunction of the RPE tight junction $[1,12]$. To confirm the protective effect of LB extract and taurine in barrier function in high glucose-treated ARPE-19 cells, claudin-1 protein expression, an indicator of barrier function at tight junction [26], was determined by Western blot analysis.

Incubation with high glucose for $48 \mathrm{~h}$ induced a significant increase in the level of claudin-1 protein expression (10.07-fold), compared with normal glucose culture (Figure 6).

LB extract $(0.1,0.5$ and $0.75 \mathrm{mg} / \mathrm{ml})$ dose-dependently downregulated claudin-1 protein expression (by 8.30-, 5.61- and 3.06fold, respectively) (Figure $6 \mathrm{a})$. Taurine $(0.001,0.1$ and $1 \mathrm{mM}$ ) dosedependently down-regulated the glucose-increased claudin-1 protein expression (by 7.73-, 4.97- and 2.82-fold, respectively) (Figure 6b). The protein levels of claudin-1 in high glucose treated cells were also decreased by the positive controls, RG (5.47-fold) and PG (2.80fold). The osmotic control did not enhance active claudin-1 protein level, excluding the involvement of osmotic effects of high glucose concentrations.

Effects of LB extract and taurine on connexin 43 protein expression in high-glucose treated ARPE-19 cells

Hyperglycemia also down-regulates gap junction protein connexin 43 , leading to degradation of RPE cells and eventual disruption of the BRB [34]. We therefore determined the effect of LB extract and taurine on connexin 43 protein levels in high glucose-treated ARPE-19 cells.

Incubation with high glucose for $48 \mathrm{~h}$ induced a significant decrease in the level of connexin 43 protein expression (0.34-fold), compared with normal glucose culture (Figure 7$)$. LB extract $(0.1,0.5$ and $0.75 \mathrm{mg} /$ $\mathrm{ml})$ dose-dependently up-regulated the glucose-decreased connexin 43 protein expression (by $0.40-, 0.66$ - and 0.99 -fold, respectively) (Figure7a). Taurine $(0.001,0.1$ and $1 \mathrm{mM}$ ) dose-dependently upregulated glucose-increased connexin 43 protein expression (by 0.58 , 0.74- and 1.01-fold, respectively) (Figure 7b). The protein levels of connexin 43 in high glucose treated cells were also increased by the

(a)

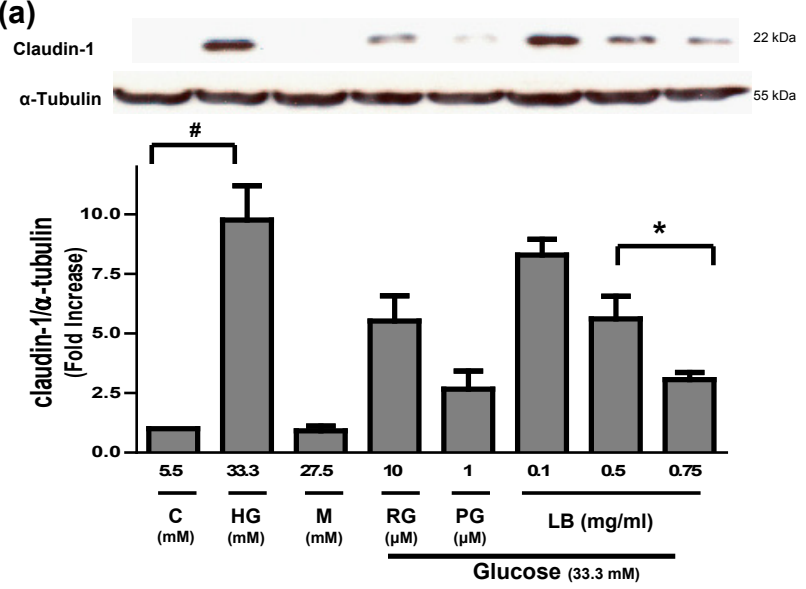

(b)

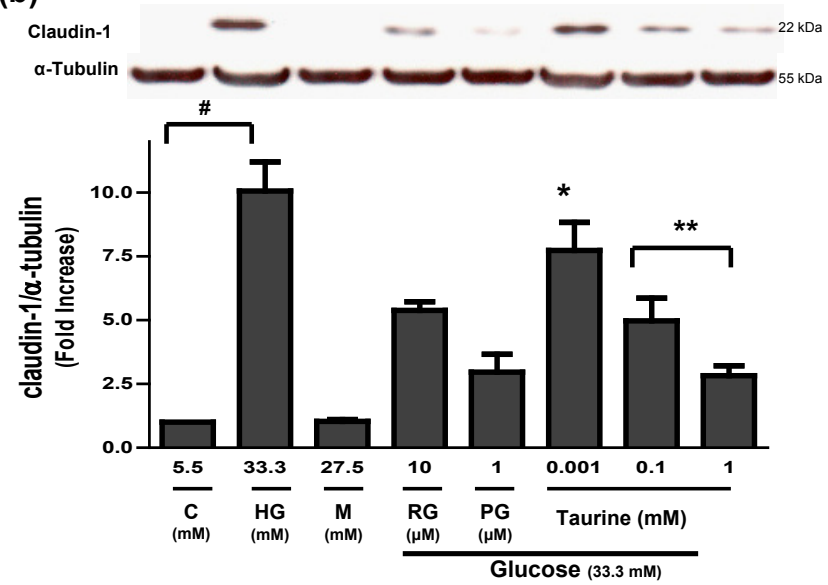

Figure 6: Effects of (a) LB extract and (b) taurine on protein expression of claudin-1 in high glucose-treated ARPE-19 cells. The relative levels of protein for claudin-1 was assessed by the immunoblotting method, and normalised to $\alpha$-tubulin. Levels in control were arbitrarily assigned a value of 1.0. Values are means \pm SEM $(n=6) .{ }^{*} P<0.001$ versus Control, ${ }^{*} P<0.05$, ${ }^{* *} P<0.01$ versus high glucose $(\mathrm{HG})$. 
Citation: Song MK, Roufogalis BD, Huang THW (2011) Modulation of RAGE and the Downstream Targets of RAGE Signaling Cascades by Taurine in Lycium Barbarum (Goji Berry): Protection of Human Retinal Pigment Epithelial Barrier Function and its Potential Benefit in Diabetic Retinopathy. J Diabetes Metab 2:162. doi:10.4172/2155-6156.1000162

positive controls, RG (0.60-fold) and PG (1.03-fold). The osmotic control did not decrease connexin 43 protein levels, excluding the involvement of osmotic effects of high glucose concentrations.

Effects of LB extract and taurine on claudin-1 and connexin 43 distribution and localisation in high-glucose treated ARPE-19 cells

To further investigate the effect of LB extract and taurine on barrier function in high glucose-treated ARPE-19 cells, we examined the morphological characteristic staining of claudin-1 (Figure 8af) and connexin 43 (Figure 8g-1) proteins by immunofluorescence analysis. Incubation with high glucose for $48 \mathrm{~h}$ induced a significant increase in the fluorescence intensity of claudin-1 (3.58-fold) (Figure $8 \mathrm{~m})$. Treatment with $\mathrm{LB}$ extract $(0.75 \mathrm{mg} / \mathrm{ml})$ and taurine $(1 \mathrm{mM})$ significantly decreased the claudin-1 fluorescence intensity (by 1.98 and 1.65 -fold, respectively) (Figure $8 \mathrm{~m}$ ). The fluorescence intensity of claudin-1 in high glucose condition was similarly decreased by the positive controls, RG (2.04-fold) and PG (1.18-fold).

Incubation with high glucose for $48 \mathrm{~h}$ induced a significant decrease in the fluorescence intensity of connexin 43 (0.37-fold) (Figure $8 \mathrm{n})$. Treatment with $\mathrm{LB}$ extract $(0.75 \mathrm{mg} / \mathrm{ml})$ and taurine $(1 \mathrm{mM})$ significantly increased the glucose-decreased connexin 43 staining intensity (by 0.89 - and 0.95 -fold, respectively) (Figure $8 \mathrm{n}$ ). The fluorescence intensity of connexin 43 in high glucose condition was similarly increased by the positive controls, RG ( 0.67 -fold) and PG (0.91-fold).

\section{Discussion}

Diabetic retinopathy (DR) is a preventable microvascular diabetic complication, and hyperglycemia is considered a major factor in its development [3]. Although various hyperglycaemia-induced metabolic abnormalities are implicated in DR [30], it has been difficult to pinpoint the exact pathophysiological mechanism, thus making the rationale for a therapeutic target difficult. Numerous studies have shown that activation of RAGE and subsequent activation of NF- $\kappa B$ transcription factor, followed by increased production of ICAM-1 and VEGF, are one of the critical factors in the breakdown of the blood retinal barrier (BRB), which eventually leads to DR [36,52].

Retinal pigment epithelial (RPE) cells form a monolayer between the neuroretina and the choriocapillaris that are the essential components of the outer $\mathrm{BRB}$ and play an important role in the pathologic process of DR $[4,49,60]$. Moreover, hyperglycemia induces inflammation in ARPE-19 cells that causes breakdown of RPE barrier function, resulting in up-regulation of claudin-1 and down-regulation of connexin 43 [1,34,57].

PPAR $-\gamma$ is heterogeneously expressed in the mammalian eye, and is prominently present in the retinal pigmented epithelium, photoreceptor outer segments and choriocapillaries [24]. A recent study has shown that retinal expression of PPAR- $\gamma$ was suppressed in experimental models of diabetes and in endothelial cells treated with high glucose [55]. In previous work which formed the background leading to the present studies we determined that LB extract and pure taurine, a major component in the LB extract, activated PPAR- $\gamma$ by luciferase reporter gene analysis and by mRNA and Western blotting measurement in human retinal pigment epithelial cells. At the same time both LB extract and pure taurine inhibited a variety of PPAR- $\gamma$ dependent downstream effectors in the retinal cells [53]. A body of evidence has shown that PPAR- $\gamma$ ligands inhibit the formation of AGEs [47,51]. PPAR- $\gamma$ agonists such as RG and pioglitazone have (a)

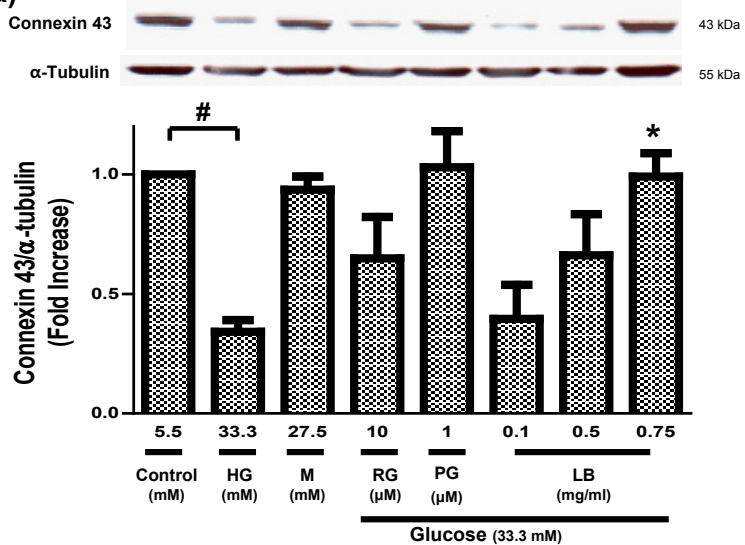

(b)

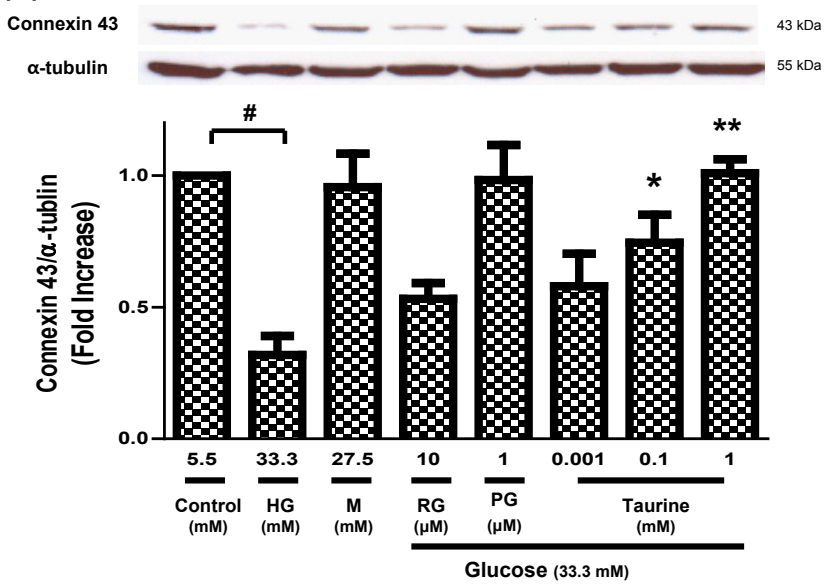

Figure 7: Effects of (a) LB extract and (b) taurine on protein expression of connexin 43 in high glucose-treated ARPE-19 cells. The relative levels of protein for connexin 43 were assessed by the immunoblotting method, and normalised to a-tubulin. Levels in control were arbitrarily assigned a value of 1.0. Values are means $\pm \operatorname{SEM}(n=6) .{ }^{\#} P<0.01$ versus Control, ${ }^{*} P<0.05,{ }^{*} P<0.01$ versus high glucose $(\mathrm{HG})$.

been shown to decrease tumor necrosis factor-alpha-induced RAGE expression via suppression of NF- $\kappa \mathrm{B}$ activation [37]. Moreover, telmisartan, an angiontensin II type 1 receptor block has shown to down-regulate RAGE expression and suppress its downstream signalings in various cells through its unique PPAR- $\gamma$-modulating ability $[38,65,68]$. PPAR- $\gamma$ ligands are also potent inhibitors of corneal angiogenesis and neovascularization [42,63]. Administration of 15d-PGJ2 inhibited VEGF-stimulated angiogenesis in rat cornea [63]. RG was shown to inhibit both retinal leukostasis and retinal leakage by the inhibition of NF- $\mathrm{kB}$ activation, with consequent suppression of ICAM-1 expression [42]. Moreover, RG has been shown to inhibit retinal neovascularization by a mechanism downstream from VEGFinduced angiogenesis [43].

In the present study we have investigated the potential of Lycium barbarum (LB), to prevent retinal barrier disruption by high glucose exposure, and examined the protein activities associated with this protection. Lycium barbarum (LB), a traditional Chinese medicine, has been used for centuries in the East and is believed to be beneficial for treating eye related disorders [8]. Different biological activities of LB have been demonstrated, including anti-aging, anti-inflammatory 
Citation: Song MK, Roufogalis BD, Huang THW (2011) Modulation of RAGE and the Downstream Targets of RAGE Signaling Cascades by Taurine in Lycium Barbarum (Goji Berry): Protection of Human Retinal Pigment Epithelial Barrier Function and its Potential Benefit in Diabetic Retinopathy. J Diabetes Metab 2:162. doi:10.4172/2155-6156.1000162

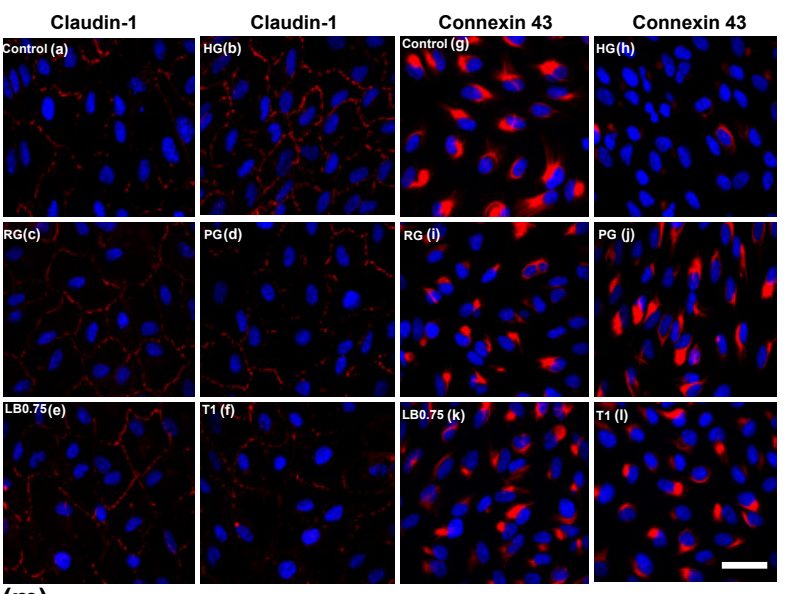

(m)

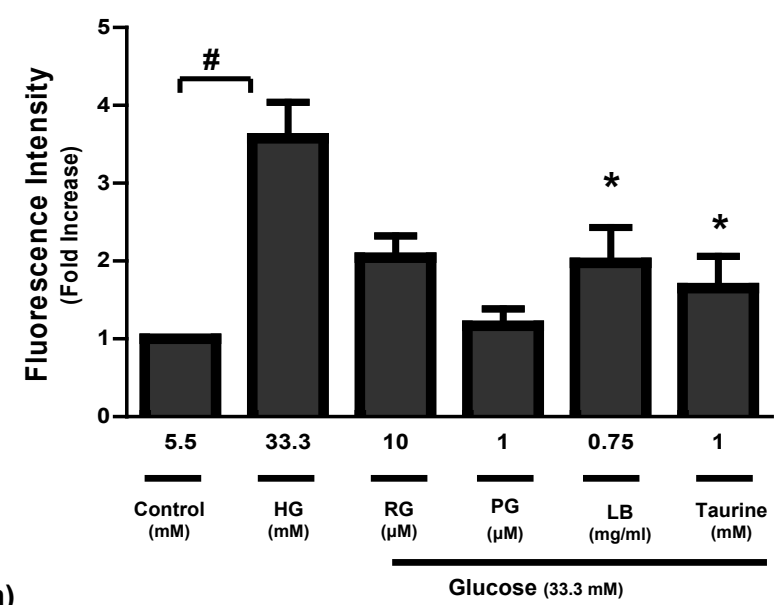

(n)

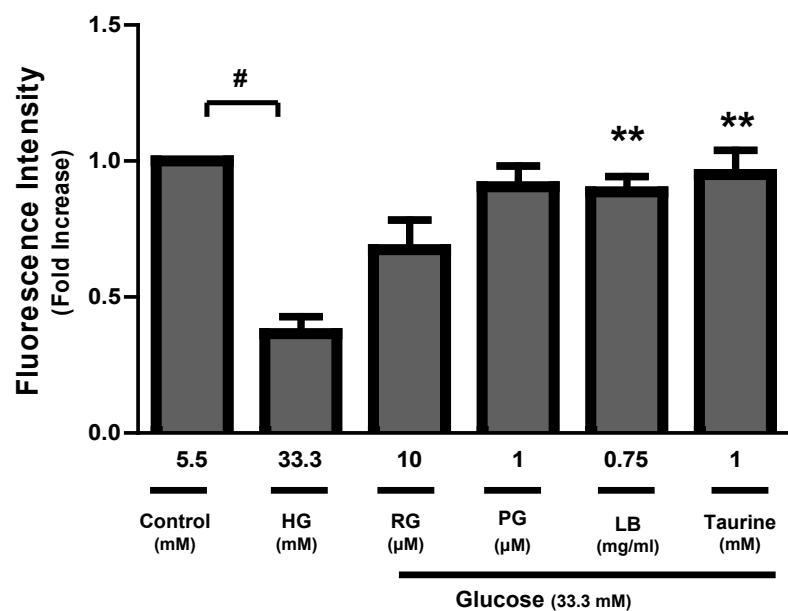

Figure 8: Immunohistochemistry of ARPE-19 cells showing the distruption of the monolayer induced by high glucose and the effects of LB extract $(0.75$ $\mathrm{mg} / \mathrm{ml})$ and taurine $(1 \mathrm{mM})$ in preventing the disorganization of claudin-1 and connexin 43 proteins and in maintaining the integrity of the monolayer. (a-f) claudin-1 and (g-I) connexin 43 staining appears in red. The intensity of $(\mathbf{m})$ claudin-1 and (n) connexin 43 staining signals (red) was quantified using the Image $\mathrm{J}$ software. Levels in control were arbitrarily assigned a value of 1.0 Values are means \pm SEM $(n=4)$. ${ }^{\#} P<0.01$ versus Control, ${ }^{*} P<0.05,{ }^{* *} P<0.01$ versus high glucose (HG). The nuclei were stained with Hoechst 33342 (blue) Scale bar $50 \mu \mathrm{m}$. HG, high glucose (33.3 mM); RG, RG (10 $\mu \mathrm{M})$; PG, PG (1 $\mu \mathrm{M})$; T1, taurine $1 \mathrm{mM}$; LB0.75, LB $(0.75 \mathrm{mg} / \mathrm{ml})$. activity and cytoprotection [33]. The crude polysaccharides from Lycium barbarum (LBP) have been shown to decrease the serum AGEs levels in a D-galactose induced mouse aging model, and reduce BRB disruption in retinal ischemia/reperfusion injury [15,32].

We have also investigated the effect of taurine, one of the major components in LB, in the retinal barrier permeability and its associated protein activities. Taurine is present in abundance in retina, and is essential for sustaining retinal structure and function [6]. Various studies have shown that plasma and tissue levels of taurine are reduced in diabetes $[19,20,23]$. Indeed, studies have shown the beneficial effect of taurine supplementation in preventing or ameliorating hyperglycemiainduced retinal defects $[20,23]$. Moreover, the studies have shown that high glucose-induced AGEs level and NF- $\kappa \mathrm{B}$ activation are inhibited by taurine, exhibiting effective prevention against diabetic-related pathology $[27,44]$. In addition, taurine has been shown to protect against hyperglycemia-induced endothelial and retinal dysfunctions through the down-regulation of ICAM-1 and VEGF levels $[58,69]$.

From previous work where we established that LB extract and the active component, taurine, delayed DR pathophysiology through PPAR- $\gamma$ activation [53] we have hypothesised that taurine, may modulate high glucose-induced disruption of RPE barrier function and that this may be associated with modulation of PPAR- $\gamma$-mediated downstream targets of RAGE signaling cascades. In order to test this hypothesis, we first investigated the effect of pure taurine and an LB extract rich in taurine on levels of RAGE protein expression in high glucose-treated ARPE-19 cells. Our results demonstrated that a methanol extract of LB dose-dependently decreased levels of RAGE protein expression (Figure 1a). The extract also decreased activation of the pro-inflammatory transcriptional factor, NF- $\kappa B$ (Figure 2). Since the methanol extract used here contained a high content of taurine $(10.66 \%)$ [53], we investigated the effect of pure taurine and showed that it had a similar effect in modulating levels of RAGE protein expression (Figure $1 \mathrm{~b}$ ) and activation of NF- $\kappa \mathrm{B}$ (Figure 2). Our study also demonstrated that both LB extract and taurine dose-dependently down-regulated the increase in pro-inflammatory mediators following exposure of RPE cells with $33.3 \mathrm{mM}$ glucose, as shown by the ICAM1 luciferase activation (Figure 3), VEGF protein expression (Figure $4 a, b)$ and VEGF levels (Figure 4c). We further examined the role of LB extract and taurine on barrier permeability function, and showed that they both attenuated high glucose induced-RPE barrier disruption, as measured by transepithelial electrical resistance (TER) (Figure 5a) and FITC-dextran permeability (Figure 5b). Moreover, LB extract and taurine were found to dose-dependently down-regulate the increase by high glucose exposure of claudin-1 tight junction protein (Figure 6a,b), and up-regulated the decrease in connexin 43 gap junction protein expression (Figure 7a,b). These findings were further confirmed by characteristic morphologic staining (Figure 8a-1) and densitometric analysis of immunoflorescence signals (Figure $8 \mathrm{~m}, \mathrm{n}$ ). The results support the proposal that taurine present in the LB extract is to a large extent responsible for the modulation of high glucose induceddisruption of RPE barrier function. The range of taurine concentrations in the LB extract used in the experiments, $0.086-0.645 \mathrm{mM}$, falls within the range of pure taurine concentrations $(0.001-1.00 \mathrm{mM})$ used [53]. Hence it can be concluded that the activities of the extracts are accounted to a large extent by their taurine content.

The results of our studies have found that taurine and LB extract are PPAR- $\gamma$ activators [53], they affect RAGE and NF- $\kappa B$ like other PPAR- $\gamma$ agonists, and that PPAR- $\gamma$ activation is known to modulate RAGE downstream modulators. However the results are unable to 
Citation: Song MK, Roufogalis BD, Huang THW (2011) Modulation of RAGE and the Downstream Targets of RAGE Signaling Cascades by Taurine in Lycium Barbarum (Goji Berry): Protection of Human Retinal Pigment Epithelial Barrier Function and its Potential Benefit in Diabetic Retinopathy. J Diabetes Metab 2:162. doi:10.4172/2155-6156.1000162

establish a direct link between taurine and LB extract activation and RAGE-dependent downstream effectors on barrier permeability. Future studies are needed to clarify the involvement of this pathway in the actions of LB and taurine. Interestingly, it has been reported in a previous study that high glucose concentration results in a reduction of permeability [59]. In contrast, a more recent study has shown that high glucose moderately increases permeability in ARPE-19 cells [57]. These differences might be explained by the different cell culture conditions. In addition, the studies have shown that the high levels of VEGF in high glucose-induced ARPE-19 cells produce a significant decrease in TER $[2,34]$. In the light of these conflicting findings, the exact mechanism of the changes in permeability in high glucose-treated ARPE-19 cells requires further investigation.

In summary, this study has demonstrated for the first time that the traditional Chinese medicine Lycium barbarum protects against high glucose barrier disruption in retinal pigment epithelial cells. It also decreases RAGE and the downstream targets of RAGE signaling cascades, consistent with the effect being mediated through the PPAR- $\gamma$ activation pathway. The effects of the extract are mimicked by taurine at concentrations identical to those present in the extracts. Though the exact mechanisms on RAGE signaling cascades has not been examined in this study, it can be speculated that taurine and, LB extract, being PPAR- $\gamma$ ligands, might be modulating RAGE signaling cascades similar to other PPAR- $\gamma$ agonists like RG, leading to protection against the high glucose barrier disruption. Delineation of the similar effects of LB extract and taurine provides a rationale for the therapeutic use of this valuable medicinal herb and its taurine component for the prevention of DR. However, further investigation into their exact mechanism warrants further translational studies to gather proof of efficacy and safety of LB for possible protection against DR in various preclinical and clinical settings.

\section{Acknowledgements}

We thank Benjamin Kimble (Faculty of Veterinary Science, The University of Sydney, Australia) for suggestions and technical instructions in the phytochemical analysis; Moon Sun Kim (Faculty of Pharmacy, The University of Sydney, Australia) for providing cellular biology materials; and the National Institute of Complementary Medicine (NICM) and the Pharmacy Faculty for a postgraduate scholarship (MKS) and funding support to BDR.

\section{References}

1. Abe T, Sugano E, Saigo Y, Tamai M (2003) Interleukin-1 beta and barrier function of retinal pigment epithelial cells (ARPE-19): Aberrant expression of junctional complex molecules. Invest Ophthalmol Vis Sci 44: 4097-4104.

2. Ablonczy Z, Crosson CE (2007) VEGF modulation of retinal pigment epithelium resistance. Exp Eye Res 85: 762-771.

3. Ali TK, El-Remessy AB (2009) Diabetic retinopathy: current management and experimental therapeutic targets. Pharmacotherapy 29: 182-192.

4. Bok D (1993) The retinal pigment epithelium: a versatile partner in vision. J Cell Sci Suppl 17: 189-195.

5. Cao G, Alessio HM, Cutler RG (1993) Oxygen-radical absorbance capacity assay for antioxidants. Free Radic Biol Med 14: 303-311.

6. Cao Y, Zhang X, Chu Q, Fang Y, Ye J (2003) Determination of Taurine in Lycium Barbarum L. and Other Foods by Capillary Electrophoresis with Electrochemical Detection. Electroanalysis 15: 898-902.

7. Chan HC, Chang RC, Koon-Ching Ip A, Chiu K, Yuen WH, et al. (2007) Neuroprotective effects of Lycium barbarum Lynn on protecting retinal ganglion cells in an ocular hypertension model of glaucoma. Exp Neurol 203: 269-273.

8. Chang RC, So KF (2008) Use of anti-aging herbal medicine, Lycium barbarum, against aging-associated diseases. What do we know so far? Cell Mol Neurobiol 28: 643-652

9. Cheng CY, Chung WY, Szeto YT, Benzie IF (2005) Fasting plasm.a zeaxanthin response to Fructus barbarum L. (wolfberry; Kei Tze) in a food-based human supplementation trial. Br J Nutr 93: 123-130

10. Chiu K, Chan HC, Yeung SC, Yuen WH, Zee SY, et al. (2009) Modulation of microglia by Wolfberry on the survival of retinal ganglion cells in a rat ocular hypertension model. J Ocul Biol Dis Infor 2: 47-56.

11. Ciulla TA, Amador AG, Zinman B (2003) Diabetic retinopathy and diabetic macular edema: pathophysiology, screening, and novel therapies. Diabetes Care 26: 2653-2664.

12. Cui HS, Hayasaka S, Zhang XY, Hayasaka Y, Chi ZL, et al. (2007) Effect of berberine on barrier function in a human retinal pigment epithelial cell line. Jpn J Ophthalmol 51: 64-67.

13. Davies GF, McFie PJ, Khandelwal RL, Roesler WJ (2002) Unique ability of troglitazone to up-regulate peroxisome proliferator-activated receptor-gamma expression in hepatocytes. J Pharmacol Exp Ther 300: 72-77.

14. Decanini A, Karunadharma PR, Nordgaard CL, Feng X, Olsen TW, et al (2008) Human retinal pigment epithelium proteome changes in early diabetes. Diabetologia 51: 1051-1061.

15. Deng HB, Cui DP, Jiang JM, Feng YC, Cai NS, et al. (2003) Inhibiting effects of Achyranthes bidentata polysaccharide and Lycium barbarum polysaccharide on nonenzyme glycation in D-galactose induced mouse aging model. Biomed Environ Sci 16: 267-275

16. Dunn KC, Aotaki-Keen AE, Putkey FR, Hjelmeland LM (1996) ARPE-19, a human retinal pigment epithelial cell line with differentiated properties. Exp Eye Res 62: 155-169.

17. Fang IM, Yang CH, Yang CM, Chen MS (2009) Comparative effects of fatty acids on proinflammatory gene cyclooxygenase 2 and inducible nitric oxide synthase expression in retinal pigment epithelial cells. Mol Nutr Food Res 53 739-750.

18. Fong DS, Aiello LP, Ferris FL, Klein R (2004) Diabetic retinopathy. Diabetes Care 27: 2540-2553

19. Franconi F, Di Leo MA, Bennardini F, Ghirlanda G (2004) Is taurine beneficial in reducing risk factors for diabetes mellitus? Neurochem Res 29: 143-150.

20. Franconi F, Loizzo A, Ghirlanda G, Seghieri G (2006) Taurine supplementation and diabetes mellitus. Curr Opin Clin Nutr Metab Care 9: 32-36.

21. Ganzera M, Zhao J, Khan IA (2001) Analysis of terpenelactones in Ginkgo biloba by high performance liquid chromatography and evaporative light scattering detection. Chem Pharm Bull (Tokyo) 49: 1170-1173.

22. Gardner TW, Antonetti DA, Barber AJ, LaNoue KF, Nakamura M (2000) New insights into the pathophysiology of diabetic retinopathy: potential cell-specific therapeutic targets. Diabetes Technol Ther 2: 601-608

23. Hansen SH (2001) The role of taurine in diabetes and the development of diabetic complications. Diabetes Metab Res Rev 17: 330-346.

24. Herzlich AA, Tuo J, Chan CC (2008) Peroxisome proliferator-activated receptor and age-related macular degeneration. PPAR Res 2008: 389507.

25. Holtkamp GM, Van Rossem M, De Vos AF, Willekens B, Peek R, et al. (1998) Polarized secretion of IL- 6 and IL-8 by human retinal pigment epithelial cells Clin Exp Immunol 112: 34-43.

26. Inai T, Kobayashi J, Shibata $Y$ (1999) Claudin-1 contributes to the epithelia barrier function in MDCK cells. Eur J Cell Biol 78: 849-855.

27. Karabay AZ, Koc A, Ozkan T, Buyukbingol Z, Sunguroglu A (2008) Effect of Taurine on Hydrogen Peroxide Production in Lipopolisaccharide Induced RAW 264.7 Macrophage Cells. FABAD J Pharm Sci 33: 187-192.

28. Kikuchi T, Hagiwara K, Honda Y, Gomi K, Kobayashi T, et al. (2002) Clarithromycin suppresses lipopolysaccharide-induced interleukin-8 production by human monocytes through AP-1 and NF-kappa B transcription factors. J Antimicrob Chemother 49: 745-755.

29. Kimoto K, Nakatsuka K, Matsuo N, Yoshioka H (2004) p38 MAPK mediates the expression of type I collagen induced by TGF-beta 2 in human retinal pigment epithelial cells ARPE-19. Invest Ophthalmol Vis Sci 45: 2431-2437.

30. Kowluru RA, Atasi L, Ho YS (2006) Role of mitochondrial superoxide dismutase in the development of diabetic retinopathy. Invest Ophthalmol Vis Sci 47: 1594 1599 .

31. Kowluru RA, Chakrabarti S, Chen S (2004) Re-institution of good metabolic 
Citation: Song MK, Roufogalis BD, Huang THW (2011) Modulation of RAGE and the Downstream Targets of RAGE Signaling Cascades by Taurine in Lycium Barbarum (Goji Berry): Protection of Human Retinal Pigment Epithelial Barrier Function and its Potential Benefit in Diabetic Retinopathy. J Diabetes Metab 2:162. doi:10.4172/2155-6156.1000162

control in diabetic rats and activation of caspase- 3 and nuclear transcriptional factor (NF-kappaB) in the retina. Acta Diabetol 41: 194-199.

32. Li SY, Yang D, Yeung CM, Yu WY, Chang RC, et al. (2011) Lycium barbarum polysaccharides reduce neuronal damage, blood-retinal barrier disruption and oxidative stress in retinal ischemia/reperfusion injury. PLoS One 6: e16380.

33. Li XM, Ma YL, Liu XJ (2007) Effect of the Lycium barbarum polysaccharides on age-related oxidative stress in aged mice. J Ethnopharmacol 111: 504-511.

34. Losso JN, Truax RE, Richard G (2010) trans-resveratrol inhibits hyperglycemiainduced inflammation and connexin downregulation in retinal pigment epithelial cells. J Agric Food Chem 58: 8246-8252.

35. Luo Q, Cai Y, Yan J, Sun M, Corke H (2004) Hypoglycemic and hypolipidemic effects and antioxidant activity of fruit extracts from Lycium barbarum. Life Sci 76: $137-149$

36. Ma W, Lee SE, Guo J, Qu W, Hudson BI, et al. (2007) RAGE ligand upregulation of VEGF secretion in ARPE-19 cells. Invest Ophthalmol Vis Sci 48: 1355-1361.

37. Marx N, Walcher D, Ivanova N, Rautzenberg K, Jung A, et al. (2004) Thiazolidinediones reduces endothelial expression of receptors for advanced glycation end products. Diabetes 53: 2662-2668.

38. Matsui T, Nakamura K, Takeuchi M, Yamagishi S (2008) Telmisartan Blocks Advanced Glycation End Product (AGE)-Induced Plasminogen Activato Inhibitor-1 (PAl-1) Gene Expression in Endothelial 1Cells via Activation of Peroxisome Proliferator-Activated Receptor-gamma(PPAR-gamma). Letters in Drug Design \& Discovery 5: 477-480.

39. McCarty MF (1997) Exploiting complementary therapeutic strategies for the treatment of type II diabetes and prevention of its complications. Med Hypotheses 49: 143-152.

40. Miho N, Ishida T, Kuwaba N, Ishida M, Shimote-Abe K, et al. (2005) Role of the JNK pathway in thrombin-induced ICAM-1 expression in endothelial cells. Cardiovasc Res 68: 289-298.

41. Moon NS, Di Stefano L, Morris EJ, Patel R, White K, et al. (2008) E2F and p53 Induce Apoptosis Independently during Drosophila Development but Intersect in the Context of DNA Damage. Plos Genetics 4: e1000153.

42. Muranaka K, Yanagi Y, Tamaki Y, Usui T, Kubota N, et al. (2006) Effects of peroxisome proliferator-activated receptor gamma and its ligand on bloodretinal barrier in a streptozotocin-induced diabetic model. Invest Ophthalmol Vis Sci 47: 4547-4552.

43. Murata T, Hata Y, Ishibashi T, Kim S, Hsueh WA, et al. (2001) Response of experimental retinal neovascularization to thiazolidinediones. Arch Ophthalmo 119: 709-717.

44. Nandhini AT, Thirunavukkarasu V, Anuradha CV (2004) Stimulation of glucose utilization and inhibition of protein glycation and AGE products by taurine. Acta Physiol Scand 181: 297-303.

45. Peng X, Tian G (2001) Structural characterization of the glycan part of glycoconjugate LbGp2 from Lycium barbarum L. Carbohydr Res 331: 95-99.

46. Poulaki V, Qin WY, Joussen AM, Hurlbut P, Wiegand SJ, et al. (2002) Acute intensive insulin therapy exacerbates diabetic blood-retinal barrier breakdown via hypoxia-inducible factor-I alpha and VEGF. J Clin Invest 109: 805-815.

47. Rahbar S, Natarajan R, Yerneni K, Scott S, Gonzales N, et al. (2000) Evidence that pioglitazone, metformin and pentoxifylline are inhibitors of glycation. Clin Chim Acta 301: 65-77.

48. Rahman A, Bando M, Kefer J, Anwar KN, Malik AB (1999) Protein kinase C-activated oxidant generation in endothelial cells signals intercellular adhesion molecule-1 gene transcription. Mol Pharmacol 55: 575-583.

49. Rizzolo LJ (1997) Polarity and the development of the outer blood-retinal barrier. Histol Histopathol 12: 1057-1067.

50. Sen R, Baltimore D (1986) Inducibility of kappa-immunoglobulin enhancerbinding protein nf-kappa-b by a posttranslational mechanism. Cell 47: 921-928.

51. Sobal G, Menzel EJ, Sinzinger H (2005) Troglitazone inhibits long-term glycation and oxidation of low-density lipoprotein. J Cardiovasc Pharmacol 46 $672-680$
52. Song MK, Roufogalis BD, Huang TH (2011) Modulation of Diabetic Retinopathy Pathophysiology by Natural Medicines through PPAR-gamma-related Pharmacology. Br J Pharmacol 165: 4-19.

53. Song MK, Salam NK, Roufogalis BD, Huang THW (2011) Lycium barbarum (Goji Berry) extracts and its taurine component inhibit PPAR-gammadependent gene transcription in human retinal pigment epithelial cells: Possible implications for diabetic retinopathy treatment. Biochemical Pharmacology 82 : 1209-1218.

54. Stitt AW (2003) The role of advanced glycation in the pathogenesis of diabetic retinopathy. Exp Mol Pathol 75: 95-108.

55. Tawfik A, Sanders T, Kahook K, Akeel S, Elmarakby A, et al. (2009) Suppression of retinal peroxisome proliferator-activated receptor gamma in experimenta diabetes and oxygen-induced retinopathy: role of NADPH oxidase. Invest Ophthalmol Vis Sci 50: 878-884.

56. Touyz RM, Schiffrin EL (2006) Peroxisome proliferator-activated receptors in vascular biology-molecular mechanisms and clinical implications. Vascul Pharmacol 45: 19-28.

57. Trudeau K, Roy S, Guo W, Hernandez C, Villarroel M, et al. (2011) Fenofibric acid reduces fibronectin and collagen type IV overexpression in human retinal pigment epithelial cells grown in conditions mimicking the diabetic milieu: Functional implications in retinal permeability. Invest Ophthalmol Vis Sci 52 6348-6354.

58. Ulrich-Merzenich G, Zeitler H, Vetter H, Bhonde RR (2007) Protective effects of taurine on endothelial cells impaired by high glucose and oxidized low density lipoproteins. Eur J Nutr 46: 431-438.

59. Villarroel M, Garcia-Ramirez M, Corraliza L, Hernandez C, Simo R (2009) Effects of high glucose concentration on the barrier function and the expression of tight junction proteins in human retinal pigment epithelial cells. Exp Eye Res 89: $913-920$

60. Wang W, Matsukura M, Fujii I, Ito K, Zhao JE, et al. (2011) Inhibition of high glucose-induced VEGF and ICAM-1 expression in human retinal pigment epithelium cells by targeting ILK with small interference RNA. Mol Biol Rep 39: $613-620$

61. Wang Y, Zhao H, Sheng X, Gambino PE, Costello B, et al. (2002) Protective effect of Fructus Lycii polysaccharides against time and hyperthermia-induced damage in cultured seminiferous epithelium. J Ethnopharmacol 82: 169-175.

62. Xie H, Zhang S (1997) [Determination of taurine in Lycium barbarum L. by high performance liquid chromatography with OPA-urea pre-column derivatization] Se Pu 15: 54-56.

63. Xin X, Yang S, Kowalski J, Gerritsen ME (1999) Peroxisome proliferatoractivated receptor gamma ligands are potent inhibitors of angiogenesis in vitro and in vivo. J Biol Chem 274: 9116-9121.

64. Yam JC, Kwok AK (2007) Update on the treatment of diabetic retinopathy Hong Kong Med J 13: 46-60.

65. Yamagishi SI, Matsui T, Nakamura K, Takeuchi M, Inoue H (2008) Telmisartan inhibits advanced glycation end products (AGEs)-elicited endothelial cell injury by suppressing AGE receptor (RAGE) expression via peroxisome proliferatoractivated receptor-gamma activation. Protein Pept Lett 15: 850-853.

66. Yao D, Brownlee M (2009) Hyperglycemia-induced reactive oxygen species increase expression of the receptor for advanced glycation end products (RAGE) and RAGE ligands. Diabetes 59: 249-255.

67. Yokoyama T, Yamane K, Minamoto A, Tsukamoto $H$, Yamashita $H$, et al. (2006) High glucose concentration induces elevated expression of anti-oxidan and proteolytic enzymes in cultured human retinal pigment epithelial cells. Exp Eye Res 83: 602-609.

68. Yoshida T, Yamagishi S, Nakamura K, Matsui T, Imaizumi T, et al. (2006) Telmisartan inhibits AGE-induced C-reactive protein production through downregulation of the receptor for AGE via peroxisome proliferator-activated receptor-gamma activation. Diabetologia 49: 3094-3099.

69. Zeng $\mathrm{K}, \mathrm{Xu} \mathrm{H}$, Mi M, Zhang Q, Zhang $\mathrm{Y}$, at al. (2009) Dietary taurine supplementation prevents glial alterations in retina of diabetic rats. Neurochem Res 34: 244-254 